\title{
Gambaran Faktor Risiko Bayi Berat Lahir Rendah yang Dirawat di RSUP DR. M. Djamil Padang Tahun 2019
}

\author{
Katelino Marpaung ${ }^{1}$, Husna Yetti ${ }^{2}$, Defrin ${ }^{3}$ \\ ${ }^{1}$ Profesi Dokter Fakultas Kedokteran Universitas Andalas Padang \\ 2 Bagian IImu Kesehatan Masyarakat - IImu Kedokteran Komunitas Fakultas Kedokteran Universitas Andalas \\ ${ }^{3}$ Bagian Obgyn Fakultas Kedokteran Universitas Andalas /RSUP Dr. M. Djamil Padang
}

A B S T R A C T yang mempunyai berat lahir kurang dari 2500_gram yang ditimbang pada saat setelah lahir. Saat ini BBLR menjadi salah satu penyebab kematian neonatus terbanyak di Kota Padang. Banyak faktor yang dapat memengaruhi kejadian bayi berat lahir rendah, seperti usia ibu, paritas, jarak kehamilan, status gizi, antenatal care, anemia, pendidikan, sosial ekonomi, penyakit saat hamil, plasenta previa, solusio plasenta, kelainan kongenital, dan kehamilan ganda.

Objektif. Penelitian ini bertujuan untuk mengetahui gambaran faktor risiko bayi berat lahir rendah yang dirawat di RSUP Dr. M. Djamil Padang pada periode 1 Januari - 31 Desembar tahun 2019.

Metode. Penelitian ini merupakan penelitian deskriptif dengan desain penelitian cross-sectional. Teknik pengambilan sampel yang digunakan adalah simple random sampling dengan jumlah sampel sebanyak 71 sampel.

Hasil. Hasil penelitian didapatkan beberapa faktor risiko sebagai berikut-: usia ibu berisiko $(28,17 \%)$, paritas nullipara $(35,21 \%)$, jarak kehamilan berisiko $(8,45 \%)$, riwayat antenatal care berisiko $(4,23 \%)$, ibu anemia $(33,80 \%)$, status pendidikan rendah $(73,24 \%)$, status sosial ekonomi rendah (54,93\%), penyakit saat hamil $(76,06 \%)$, kelainan plasenta $(5,63 \%)$, kelainan kongenital $(8,45 \%)$, dan kehamilan ganda $(22,54 \%)$.

Kesimpulan. Faktor risiko yang paling banyak terjadi pada bayi berat lahir rendah adalah penyakit saat hamil, status pendidikan rendah, dan status sosial ekonomi rendah.

Kata kunci: BBLR, faktor risiko, neonatus

Background. Low Birth Weight ( $L B W$ ) baby is when the infant is weighed less than 2500 grams at the time after birth. Low Birth Weight baby is one of the leading causes of neonates' deaths in Padang. There are several factors causing LBW babies, such as maternal age, parity, space between pregnancy, nutrition, antenatal care, anemia, low educational status, low socioeconomic status, disease during pregnancy, placenta previa, placenta abruption, congenital abnormality, and multiple pregnancies.

Objective. This study was aimed to describe the risk factors of LBW babies who were treated at RSUP Dr. M. Djamil Padang from 1st January - 31st December 2019.
Results. The results of the study describe risk factors of LBW babies as follows mother with threatening age (28.17\%), nullipara parity (35.21\%), the distance of hazardous pregnancies (8.45\%), nutritional status of underweight (12.68\%), history of risky antenatal care (4.23\%), maternal anemia (33.80\%), low educational status (73.24\%), low socioeconomic status (54.93\%), illness during pregnancy (76.06\%), placental disorders (5.63) \%), congenital abnormalities (8.45\%), and multiple pregnancies (22.54\%).

Conclusion. The most critical risk factors for low birth weight babies are illness during pregnancy, low education status, and low socioeconomic status.

Keywords: low birth weight baby, risk factors, neonates

\section{Apa yang sudah diketahui tentang topik ini?}

Terdapat berbagai faktor risiko yang dapat menyebabkan terjadinya BBLR, seperti usia ibu, paritas, jarak kehamilan, status gizi, antenatal care, anemia, pendidikan, sosial ekonomi, penyakit saat hamil, plasenta previa, solusio plasenta, kelainan kongenital, dan kehamilan ganda.

\section{Apa yang ditambahkan pada studi ini?}

Faktor risiko yang paling banyak terjadi pada bayi berat lahir rendah adalah penyakit saat hamil, pendidikan rendah, dan sosial ekonomi rendah.

\section{CORRESPONDING AUTHOR}

Phone: 085264412783

E-mail: husnavetti@med.ac.id

\section{ARTICLE INFORMATION}

Received: June $2^{\text {nd }}, 2020$

Revised: April 11 ${ }^{\text {th }}, 2021$

Available online: May $27^{\text {th }}, 2021$ 


\section{Pendahuluan}

Angka Kematian Bayi (AKB) adalah salah satu indikator yang dapat digunakan dalam menentukan derajat kesehatan suatu negara. Angka kematian bayi merupakan jumlah bayi yang meninggal sebelum mencapai usia satu tahun yang dinyatakan dalam 1000 kelahiran hidup pada tahun tersebut. ${ }^{1}$ Penelitian yang dilakukan oleh Susanty (2018) tentang kajian faktor-faktor penyebab kematian bayi di Kota Padang, didapatkan hasil terdapat hubungan yang sangat signifikan antara Bayi Berat Lahir Rendah (BBLR) terhadap kematian bayi di Kota Padang dengan nilai $\mathrm{OR}=17,2$, artinya BBLR memiliki risiko 17,2 kali lebih besar untuk mengalami kematian jika dibandingkan dengan bayi berat badan lahir normal. $^{2}$

Bayi berat lahir rendah adalah bayi yang mempunyai berat lahir kurang dari 2500_gram yang ditimbang pada saat setelah lahir. ${ }^{3}$ Berdasarkan data World Health Organization (WHO), BBLR berkontribusi 60\% sampai $80 \%$ dari semua kematian neonatus. Secara global prevalensi BBLR adalah 15,5\%, yang berjumlah sekitar 20 juta BBLR yang lahir setiap tahun, dan $96,5 \%$ di antaranya terdapat di negara berkembang. ${ }^{4}$

Berdasarkan data Riset Kesehatan Dasar (Riskesdas) 2018, proporsi bayi berat lahir rendah sebesar 6,2\% dari seluruh kelahiran. ${ }^{5}$ Berdasarkan data Dinas Kesehatan Sumatera Barat pada tahun 2017 terdapat 9,6\% BBLR dari 93.590 kelahiran hidup. ${ }^{6}$ Kejadian BBLR pada tahun 2017 di kota Padang adalah 1,5\% dan meningkat menjadi $1,8 \%$ pada tahun $2018 .{ }^{7}$

Faktor risiko terjadinya bayi berat lahir rendah dibagi menjadi faktor maternal, faktor janin ${ }_{2}$ dan faktor plasenta. Faktor maternal diantaranya maternal malnutrisi, gemeli, paparan asap rokok, konsumsi alkohol saat hamil, usia ibu saat hamil, jarak kehamilan yang berisiko, paritas dan sosial ekonomi yang rendah. Faktor janin diantaranya kelainan genetik; dan kelainan kongenital. Faktor plasenta diantaranya insufisiensi plasenta, plasenta previa, dan solusio plasenta. ${ }^{8}$

Penelitian yang dilakukan oleh Suryati (2013) mengenai faktor-faktor yang memengaruhi kejadian bayi berat lahir rendah di wilayah kerja Puskesmas Air Dingin pada tahun 2013, terdapat hubungan yang signifikan terhadap proporsi peningkatan berat badan berisiko, anemia, kekurangan energi kronik (KEK), dan jarak kehamilan. ${ }^{17}$ Usia, riwayat melahirkan BBLR, dan penyakit saat hamil akan meningkatkan risiko kejadian BBLR. ${ }^{18}$ Penelitian lain juga menyebutkan bahwa anemia pada ibu, paritas, dan Antenatal Care (ANC) yang tidak baik juga meningkatkan risiko kejadian BBLR. ${ }^{19,20}$

Untuk mencegah BBLR, faktor risiko utamanya yang dapat dimodifikasi perlu dipahami. Dengan mengetahui faktor tersebut, maka dapat dilakukan kegiatan intervensi yang tepat sasaran sehingga angka kejadian BBLR dapat diturunkan. ${ }^{13}$

Berdasarkan data kejadian bayi berat lahir rendah di kota Padang mengalami peningkatan dari tahun 2017 sampai 2018, RSUP Dr. M Djamil Padang merupakan rumah sakit tipe A di sumatera barat dan salah satu rumah sakit pendidikan. Kejadian bayi berat lahir rendah yang lahir di RSUP Dr. M Djamil cukup tinggi dan selalu mengalami peningkatan setiap tahunnya.

\section{Metode}

Jenis penelitian ini adalah penelitian deskriptif dengan desain penelitian cross-sectional study. Penelitian dilaksanakan di bagian Rekam Medik RSUP Dr. M Djamil Padang dengan periode waktu penelitian Februari sampai Maret 2020. Populasi penelitian ini adalah seluruh seluruh bayi yang didiagnosis mengalami BBLR dan dirawat di RSUP Dr. M. Djamil Padang pada periode 1 Januari - 31 Desember tahun 2019. Sampel penelitian dipilih secara simple random sampling dari semua populasi. Kriteria inklusi pada penelitian ini adalah: bayi yang didiagnosis mengalami BBLR dan dirawat pada tahun 2019 di RSUP Dr. M. Djamil Padang. Kriteria eksklusi pada penelitian ini adalah: data rekam medis yang tidak lengkap dan sampel tidak dapat dihubungi atau tidak bersedia memberikan informasi.

Instrumen dalam penelitian ini menggunakan data primer yang didapatkan dengan wawancara melalui telepon dan data sekunder, yaitu data rekam medis pasien yang terdapat di bagian rekam medis RSUP Dr M. Djamil Padang.

Data dianalisis secara univariat berdasarkan variabel yang dinilai. Analisis univariat dilakukan untuk melihat distribusi frekuensi dari masingmasing variabel. Penelitian ini telah lulus kaji etik dengan nomor surat: 22/KEPK/2020 dari bagian etik RSUP Dr. M. Djamil Padang. 
Hasil

Total sampel pada penelitian ini berjumlah 71 sampel yang telah memenuhi kriteria inklusi dan eksklusi penelitian.

\section{Karakteristik Bayi Berat Lahir Rendah}

Tabel 1 menunjukkan bahwa berdasarkan klasifikasi berat lahir, proporsi tertinggi terdapat pada kategori Bayi Berat Lahir Rendah (BBLR) $45,07 \%$, kemudian kategori Bayi Berat Lahir Sangat Rendah (BBLSR) 36,62\% dan Bayi Berat Lahir Amat Sangat Rendah (BBLASR) 18,31\%. Berdasarkan usia gestasi saat lahir didapatkan bahwa 68 bayi lahir dengan preterm $(95,77 \%)$ dan 3 bayi lahir dengan aterm $(4,23 \%)$ dan tidak terdapat bayi dengan usia gestasi postterm. Berdasarkan klasifikasi berat lahir dan usia gestasi didapatkan bahwa 45 (63,38\%) bayi Sesuai Masa Kehamilan (SMK), 23 (32,39\%) bayi Kecil Masa Kehamilan (KMK) dan 3(4,23\%) bayi Besar Masa Kehamilan (BMK).

Tabel 1. Distribusi Frekuensi Karakteritik Bayi Berat Lahir Rendah

\begin{tabular}{llrr}
\hline \multicolumn{1}{c}{ Klasifikasi } & n & \% \\
\hline Berat lahir & & & \\
& BBLR & 32 & 45,07 \\
& BBLSR & 26 & 36,62 \\
BBLASR & 13 & 18,31 \\
Usia gestasi & & \\
& Aterm & 3 & 4,23 \\
& Preterm & 68 & 95,77 \\
& Postterm & 0 & 0 \\
Berat lahir dan usia gestasi & & \\
& KMK & 23 & 32,39 \\
& SMK & 45 & 63,38 \\
BMK & 3 & 4,23 \\
lumlah & & 71 & 100 \\
\hline
\end{tabular}

\section{Distribusi Frekuensi Faktor Risiko Bayi} Berat lahir Rendah yang Dirawat di RSUP Dr.M. Djamil Padang

Pada tabel 2, faktor risiko yang memiliki persentasi cukup besar dalam kejadian BBLR terdapat pada pendidikan rendah $(73,24 \%)$, sosial ekonomi rendah $(54,93 \%)$, penyakit saat hamil (76,06\%). Pada penelitian ini pendidikan rendah artinya pendidikan ibu hanya tamatan SMA/SMP/SD/tidak bersekolah.

Pengklasifikasikan sosial ekonomi rendah jika pendapatan keluarga dibawah Upah Minimum Regional (UMR) Sumatera Barat tahun 2019. Penyakit penyerta yang dialami ibu berdasarkan hasil penelitian antara lain: preeklampsi, eklampsi, tumor tiroid, atrial septal defect, HBsAg+, Tb paru, hipertiroid, DM, mitral regurgitasi, ventricular septal defect, leukemia, gagal ginjal, dan SLE. Sebaliknya ditemukan jumlah presentasi yang lebih kecil untuk keadaan ibu yang memiliki faktor risiko, seperti usia berisiko $(28,17 \%)$, paritas nullipara $(35,21 \%)$, jarak kehamilan berisiko (8,45\%), riwayat kunjungan ANC berisiko (4,23\%), ibu anemia (33,80\%). ANC diklasifikasikan berisiko jika selama masa kehamilan ibu melaksanakan ANC kurang dari empat kali.

Faktor risiko usia berisiko dengan proporsi tertinggi terdapat pada kategori BBLR. Faktor risiko nullipara, riwayat kunjungan ANC berisiko, kondisi sosial ekonomi rendah dengan proporsi tertinggi terdapat pada kategori BBLSR. Faktor risiko jarak kehamilan berisiko, ibu anemia, tingkat pendidikan yang rendah dan adanya penyakit penyerta saat hamil dengan proporsi tertinggi terdapat kategori BBLASR.

Hasil penelitian mengenai faktor risiko kelainan plasenta, hanya terdapat kelainan berupa plasenta previa sebanyak 5,63\%, 2 bayi pada kategori BBLR dan 2 bayi pada kategori BBLSR. Tidak terdapat kelainan plasenta berupa solusio plasenta maupun kelainan plasenta lainnya. Bayi yang lahir dengan kelainan kongenital terdapat $8,45 \%$ dari seluruh bayi dengan proporsi terbanyak pada kategori BBLR sebanyak 3 bayi. Kelainan kongenital yang dialami bayi berdasarkan hasil penelitian antara lain: paten ductus arterious, atresia ani, agenesis ginjal, Congenital Talipes EquinoVarus (CTEV), tetralogy of fallot. Bayi lahir dari kehamilan ganda terdapat $22,54 \%$, dengan proporsi terbanyak pada kategori BBLSR (34,61\%).

Tabel 2. Distribusi Frekuensi Faktor Risiko Bayi Berat lahir Rendah yang Dirawat di RSUP Dr.M. Djamil Padang

\begin{tabular}{|c|c|c|c|c|c|c|c|}
\hline \multirow{3}{*}{ Variabel } & \multicolumn{6}{|c|}{ BBLR } & \multirow{3}{*}{$\%$} \\
\hline & \multicolumn{2}{|c|}{ BBLR } & \multicolumn{2}{|c|}{ BBLSR } & \multicolumn{2}{|r|}{$\begin{array}{c}\text { BBLAS } \\
\text { R }\end{array}$} & \\
\hline & n & $\%$ & $\mathbf{n}$ & $\%$ & $\mathbf{n}$ & $\%$ & \\
\hline Usia Ibu & & & & & & & \\
\hline Berisiko & 10 & 31,25 & 6 & 23,08 & 4 & 30,77 & 28,17 \\
\hline $\begin{array}{l}\text { Tidak } \\
\text { berisiko }\end{array}$ & 22 & 68,75 & $\begin{array}{l}2 \\
0\end{array}$ & 76,92 & 9 & 69,23 & 71,83 \\
\hline Paritas & & & & & & & \\
\hline Nullipara & 10 & 31,25 & $\begin{array}{l}1 \\
2\end{array}$ & 46,15 & 3 & 23,08 & 35,21 \\
\hline Primipara & 4 & 12,5 & 6 & 23,08 & 4 & 30,77 & 19,72 \\
\hline Multipara & 16 & 50 & 8 & 30,77 & 6 & 46,15 & 42,25 \\
\hline $\begin{array}{l}\text { Grande } \\
\text { multipara }\end{array}$ & 2 & 6,25 & 0 & 0 & 0 & 0 & 2,28 \\
\hline
\end{tabular}




\begin{tabular}{|c|c|c|c|c|c|c|c|}
\hline \multirow{3}{*}{ Variabel } & \multicolumn{6}{|c|}{ BBLR } & \multirow{3}{*}{$\%$} \\
\hline & \multicolumn{2}{|c|}{ BBLR } & \multicolumn{2}{|c|}{ BBLSR } & \multicolumn{2}{|c|}{ BBLASR } & \\
\hline & $\mathbf{n}$ & $\%$ & n & $\%$ & $\mathbf{n}$ & $\%$ & \\
\hline \multicolumn{8}{|l|}{ Jarak } \\
\hline \multicolumn{8}{|l|}{ Kehamilan } \\
\hline \multirow[t]{2}{*}{ Berisiko } & 2 & 6,25 & 1 & 3,85 & 3 & 23,0 & 8,45 \\
\hline & & & & & & 7 & \\
\hline Tidak & 3 & 93,7 & 25 & 96,1 & 10 & 76,9 & 91,5 \\
\hline berisiko & 0 & 5 & & 5 & & 2 & 5 \\
\hline \multicolumn{8}{|l|}{ ANC } \\
\hline Berisiko & 0 & 0 & 2 & 7,69 & 1 & 7,69 & 4,23 \\
\hline Tidak & 3 & 100 & 24 & 92,3 & 12 & 92,3 & 95,7 \\
\hline berisiko & 2 & & & 1 & & 1 & 7 \\
\hline \multicolumn{8}{|l|}{ Ibu anemia } \\
\hline \multirow[t]{2}{*}{ Anemia } & 1 & 31,2 & 9 & 34,6 & 5 & 38,4 & 33,8 \\
\hline & 0 & 5 & & 1 & & 6 & 0 \\
\hline Tidak & 2 & 68,7 & 17 & 65,3 & 7 & 53,8 & 66,2 \\
\hline anemia & 2 & 5 & & 9 & & 4 & 0 \\
\hline \multicolumn{8}{|l|}{ Pendidika } \\
\hline Rendah & 23 & 71,87 & 17 & 65,39 & 12 & 92,3 & 73,2 \\
\hline & & & & & & 1 & 4 \\
\hline Tinggi & 9 & 28,13 & 9 & 34,61 & 1 & 7,69 & 26,7 \\
\hline & & & & & & & 6 \\
\hline \multicolumn{8}{|l|}{ Sosial } \\
\hline \multicolumn{8}{|l|}{ Ekonomi } \\
\hline Rendah & 16 & 50 & 16 & 61,54 & 7 & 53,8 & 54,9 \\
\hline & & & & & & 5 & 3 \\
\hline Cukup & 16 & 50 & 10 & 38,46 & 6 & 46,1 & 45,0 \\
\hline & & & & & & 5 & 7 \\
\hline \multicolumn{8}{|l|}{ Penyakit } \\
\hline Ada & 21 & 65,63 & 20 & 76,92 & 13 & 100 & 76,0 \\
\hline Tidak & 11 & 34,37 & 6 & 23,08 & 0 & 0 & $\begin{array}{r}6 \\
23,9\end{array}$ \\
\hline ada & & & & & & & 4 \\
\hline \multicolumn{8}{|l|}{ Kelainan } \\
\hline Plasenta & & & & & & & \\
\hline $\begin{array}{l}\text { Plasenta } \\
\text { previa }\end{array}$ & 2 & 6,25 & 2 & 7,69 & 0 & 0 & 5,63 \\
\hline Solusio & 0 & 0 & 0 & 0 & 0 & 0 & 0 \\
\hline plasenta & & & & & & & \\
\hline Kelainan & 0 & 0 & 0 & 0 & 0 & 0 & 0 \\
\hline $\begin{array}{l}\text { plasenta } \\
\text { Laiinya }\end{array}$ & & & & & & & \\
\hline Plasenta & 30 & 93,75 & 24 & 92,31 & 13 & 100 & 94,3 \\
\hline normal & & & & & & & 7 \\
\hline Kelainan & & & & & & & \\
\hline Kongenital & & & & & & & \\
\hline Ada & 3 & 9,37 & 2 & 7,69 & 1 & 7,69 & 8,45 \\
\hline Tidak & 29 & 90,63 & 24 & 92,31 & 12 & 92,3 & 91,5 \\
\hline ada & & & & & & 1 & 5 \\
\hline Kehamilan & & & & & & & \\
\hline Ganda & & & & & & & \\
\hline Ada & 5 & 15,63 & 9 & 34,61 & 2 & 15,3 & 22,5 \\
\hline & & & & & & 8 & 4 \\
\hline Tidak & 27 & 84,37 & 17 & 65,39 & 11 & 84,6 & 77,4 \\
\hline ada & & & & & & 2 & 6 \\
\hline Jumlah & 32 & 100 & 26 & 100 & 13 & 100 & 100 \\
\hline
\end{tabular}

\section{Pembahasan}

\section{Karakteristik Bayi Berat Lahir Rendah}

Hasil penelitian mengenai karakteristik bayi berat lahir rendah berdasarkan berat lahir menunjukkan bahwa proporsi terbanyak bayi berada pada kategori BBLR $(45,07 \%)$ kemudian BBLSR (36,62\%) dan BBLASR (18,31\%). Hasil penelitian ini relevan dengan penelitian yang dilakukan oleh Hapsari (2017) yang mendapatkan hasil bahwa kategori BBLR memiliki proporsi tertinggi dengan jumlah $76,4 \%$, diikuti kategori BBLSR $(17,9 \%)$ dan BBLASR $(5,7 \%) \cdot{ }^{14}$ Hal ini diakibatkan perbedaan usia gestasi bayi saat lahir. Berdasarkan teori, berat badan bayi bertambah sesuai usia gestasi bayi tersebut. ${ }^{15}$

Karakteristik usia gestasi menunjukkan bahwa sebagian besar bayi lahir dalam keadaan preterm $95,77 \%$ dan aterm hanya $4,23 \%$ serta tidak terdapat bayi yang lahir dengan postterm. Persalinan aterm adalah pengeluaran buah kehamilan antara 37 minggu dan 42 minggu dan persalinan preterm adalah pengeluaran buah kehamilan $<37$ minggu usia kehamilan. Persalinan postterm pengeluaran buah kehamilan $>42$ minggu usia kehamilan. Penelitian Septa (2011) menyajikan data yang relevan, jumlah BBLR yang lahir preterm sebanyak 65\% dan aterm sebanyak $35 \%$. Faktor umur kehamilan mempengaruhi kejadian BBLR oleh karena semakin pendek masa kehamilan maka semakin kurang sempurna pertumbuhan tubuh bayi; sehingga akan turut mempengaruhi berat lahir bayi. ${ }^{15}$ Tingginya kejadian bayi yang lahir dalam keadaan preterm karena sebagian besar ibu hamil dengan penyakit penyerta, hal ini mempengaruhi kondisi kehamilan ibu dan janin. Hal ini di buktikan oleh hasil penelitian Hapsari (2017) sebagian besar bayi berat lahir rendah lahir dengan usia gestasi preterm sebanyak $82,18 \%$ dan aterm $17,82 \%$, Pada penlitian ini juga di dapatkan hasil bahwa $66,98 \%$ bayi lahir dari ibu dengan penyakit penyerta. ${ }^{14}$

Berdasarkan karakteristik berat lahir dan usia gestasi, hasil penelitian menunjukan bahwa sebagian besar bayi yang lahir berada pada klasifikasi SMK, kemudian KMK dan BMK. Hal ini menunjukan bahwa banyak bayi yang lahir dengan berat badan sesuai dengan usia gestasi saat dilahirkan. Penelitian Purba dkk (2019) menyajikan data dengan proporsi SMK 87,35\%, KMK 7,06\%, dan BMK 5,59\%. ${ }^{17}$ Berat badan bayi baru lahir ditentukan oleh faktor genetik dan status gizi janin. Status gizi janin ditentukan antara lain oleh status gizi ibu mulai dari masa konsepsi hingga melahirkan. Klasifikasi berat lahir 
dan usia gestasi mencerminkan kecukupan nutrisi intrauterin. ${ }^{18,19}$ Hasil penelitian ini menunjukan sebagian besar bayi lahir dengan kondisi nutrisi intauterin yang baik, hal ini terlihat berdasarkan hasil penelitian dimana $63,38 \%$ bayi lahir dengan klasifikasi SMK.

\section{Distribusi Frekuensi Faktor Risiko Bayi Berat lahir Rendah yang Dirawat di RSUP Dr.M. Djamil Padang}

Hasil penelitian ini menunjukkan bahwa sebagian besar ibu yang melahirkan bayi berat lahir rendah di RSUP Dr M Djamil Padang pada tahun 2019 berada pada rentang usia tidak berisiko (20-35 tahun). Hal ini sejalan dengan penelitian yang dilakukan oleh Putri (2015) dengan hasil $82,29 \%$ ibu yang melahirkan bayi berat lahir rendah memiliki usia tidak berisiko. ${ }^{16}$ Banyaknya faktor-faktor yang dapat menyebabkan bayi berat lahir rendah meskipun hamil dengan usia tidak berisiko dapat menjadi penyebab lahirnya bayi berat lahir rendah dari usia tidak bersiko. ${ }^{20}$ Berdasarkan hasil penelitian, sebagian besar ibu hamil berada pada usia reproduktif.

Status paritas ibu pada penelitian ini menunjukkan bahwa proporsi terbanyak BBLR lahir dengan status paritas ibu multipara, kemudian diikuti nullipara, primipara dan grande multipara. Paritas yang berisiko melahirkan BBLR adalah paritas 0 yaitu bila ibu pertama kali hamil dan mempengaruhi kondisi kejiwaan serta janin yang dikandungnya, dan paritas lebih dari 4 yang dapat berpengaruh pada kehamilan berikutnya karena kondisi ibu belum pulih jika hamil kembali. ${ }^{16}$

Faktor risiko jarak kehamilan, sebagian besar bayi lahir dari jarak kehamilan tidak berisiko ( $\geq 2$ tahun). Penelitian Mahayana (2012) menghasilkan data yang relevan yaitu $91,55 \%$ bayi lahir dari jarak kehamilan tidak berisiko. ${ }^{11}$ Banyaknya bayi yang lahir dari paritas nullipara (36\%) yang mana secara otomatis akan berada pada jarak kehamilan tidak berisiko, hal ini diakibatkan karena paritas nullipara merupakan kehamilan pertama yang artinya untuk faktor risiko jarak kehamilan secara teori akan berada pada jarak kehamilan yang tidak berisiko. Ibu yang baru melahirkan memerlukan waktu 2 sampai 3 tahun untuk hamil kembali agar pulih secara fisiologi dari kehamilan dan persalinan. Hal

https://doi.org/10.25077/ jikesi.v1i3.20 ini sangat penting untuk mempersiapkan diri untuk menghadapi kehamilan berikutnya. Semakin kecil jarak antara kedua kelahiran, semakin besar risiko untuk melahirkan BBLR. Kejadian tersebut disebabkan oleh komplikasi perdarahan waktu hamil dan melahirkan, partus prematur dan anemia berat. ${ }^{10}$

Sebagian besar ibu yang melahirkan BBLR melakukan pemeriksaan antenatal care dengan baik (tidak berisiko) pada petugas kesehatan. Hasil penelitian ini diperkuat oleh penelitian yang dilakukan oleh Fatimah (2015) di RSUP Dr. M. Djamil Padang dengan frekuensi ANC $\geq 4$ kali sebesar 73,8\%.12 Hasil penelitian ini menunjukkan bahwa sebagian besar frekuensi kunjungan ANC ibu hamil sudah baik. Hal ini sejalan dengan program pemerintah yang menganjurkan ANC minimal 4 kali selama kehamilan. ${ }^{21}$ Berdasarkan rekomendasi dari hasil penelitian yang dilakukan oleh Ginandjar (2013) bahwa ibu hamil yang memiliki penyakit penyerta saat hamil baik yang telah dialami setelah atau sebelum hamil untuk melakukan pemantauan melalui pemeriksaan ANC secara teratur minimal 4 kali. Hal ini dilakukan agar kesehatan ibu dan janin dapat terpantau dengan baik. Bagi tenaga kesehatan untuk melakukan kunjungan rumah bagi ibu hamil yang tidak terpantau atau yang tidak melakukan ANC. ${ }^{22}$

Hasil pemeriksaan darah berupa kadar haemoglobin ibu hamil pada penelitian ini menunjukkan bahwa lebih dari setengah sampel ibu memiliki kadar heemoglobin diatas $11 \mathrm{mg} / \mathrm{dl}$ (normal). Hasil penelitian Hussain et al (2018) mendapatkan hasil 56,92\% BBLR lahir dari ibu tidak anemia. ${ }^{23}$ Selama masa kehamilan, terjadi anemia relatif pada ibu, yaitu kejadian hemodilusi. Hal ini terjadi karena penambahan volume plasma relatif yang lebih besar daripada volume sel darah merah Anemia dapat mengakibatkan penurunan suplai oksigen ke jaringan, selain itu juga dapat merubah struktur vaskularisasi plasenta, hal ini akan mengganggu pertumbuhan janin sehingga akan memperkuat risiko terjadinya persalinan prematur dan kelahiran bayi dengan berat badan lahir rendah. ${ }^{24}$ Banyaknya ibu yang memiliki hb $\geq 11 \mathrm{mg} / \mathrm{dl}$ dikarenakan tingginya pencapaian ANC yang dibuktikan pada penelitian ini bahwa sebagian besar ibu memiliki riwayat kunjungan ANC yang baik. Hal ini sesuai dengan standar minimal pelayanan ANC yaitu pemberian tablet besi minimal 90 tablet selama hamil. Pemberian

Katelino Marpaung 
tablet besi dapat menurunkan kejadian anemia pada ibu hamil. ${ }^{21}$

Pada penelitian ini, sebagian besar ibu yang melahirkan bayi berat lahir rendah memiliki tingkat pendidikan rendah yang hanya tamatan sekolah menengah atas kebawah. Penelitian Borah (2016) menghasilkan data yang relevan, dimana $83 \%$ ibu berpendidikan rendah dan $16,2 \%$ ibu berpendidikan tinggi melahirkan bayi berat lahir rendah. ${ }^{25}$ Pendidikan yang rendah sangat mempengaruhi pengetahuan seseorang mengenai kesehatan. Secara teori kejadian BBLR tinggi pada ibu dengan pendidikan rendah, semakin tinggi pendidikan ibu maka semakin kecil risiko terjadinya BBLR. Pendidikan tinggi akan menunjukkkan tingkat pengetahuan seseorang tentang kesehatan. ${ }^{26}$

Lebih dari setengah sampel bayi lahir dari keluarga dengan kondisi sosial ekonomi rendah. Pendapatan ayah dan ibu berada di bawah UMR provinsi membuat sosial ekonomi keluarga tidak begitu baik yang akan berdampak pada nutrisi yang dikonsumsi ibu sebelum dan saat hamil. Berdasarkan penelitian yang dilakukan Deshpande et al (2011) terdapat hubungan yang sangat signifikan antara sosial ekonomi rendah dengan kejadian bayi berat lahir rendah. ${ }^{27}$ Perempuan dari status sosial ekonomi rendah lebih rentan terhadap infeksi serta pola makan yang buruk. Keadaan sosial ekonomi yang baik juga dapat menjamin kecukupan nutrisi selama hamil untuk mendapatkan hasil pertumbuhan dan perkembangan janin yang optimal. Selain itu, keadaan sosial ekonomi yang baik juga menjauhkan ibu hamil dari keadaan stres yang dapat mengganggu keseimbangan hormonal ibu. 27,28

Penyakit yang diderita ibu saat hamil memiliki dampak yang sangat besar sehingga bayi lahir dengan berat badan kurang dari 2500 gram. Secara keseluruhan BBLR pada penelitian ini lahir dari ibu dengan penyakit penyerta saat hamil. Penyakit yang diderita ibu juga menjadi alasan banyak bayi berat lahir rendah dalam kondisi prematur, terutama ibu yang mengalami preeklampsi berat dan eklampsi. Riwayat penyakit yang diderita ibu selama hamil seperti : hipertensi, preeklampsi, eklampsi, anemia, dibetes mellitus dan penyakit kronik lainnya dapat berdampak pada kehamilan dan janin yang dikandungnya, seperti abortus, persalinan prematur dan BBLR. ${ }^{9}$ Hasil analisis penelitian yang dilakukan Indrasari (2012) menunjukkan adanya hubungan yang signifikan antara riwayat penyakit ibu dengan kejadian BBLR, dimana ibu dengan riwayat penyakit ibu, mempunyai risiko 4,0 kali lebih besar untuk terjadi BBLR dibanding ibu yang tidak mempunyai riwayat penyakit saat hamil. ${ }^{10}$

Secara keseluruhan BBLR pada penelitian ini lahir dengan plasenta normal, hanya ada 5,63\% bayi yang lahir dengan plasenta previa. Altuncu et al (2006) menyatakan terdapat $1 \%$ ibu yang mengalami plasenta previa dan $2 \%$ ibu yang mengalami solusio plasenta yang melahirkan bayi berat lahir rendah. ${ }^{29}$ Penelitian Mahayana (2015) didapatkan hasil bahwa hanya $15,28 \%$ bayi yang lahir dari plasenta previa. ${ }^{11}$

Secara keseluruhan, BBLR pada penelitian ini lahir tanpa kelainan kongenital. Banyaknya faktor seperti genetik yang dapat mempengaruhi terjadinya kelainan kongenital pada bayi sehingga meskipun lahir dengan berat yang rendah namun seluruh organ tubuh dalam keadaan utuh. Hasil penelitian ini didukung oleh penelitian yang dilakukan Indrasari (2012) dengan hasil hanya sebagian kecil bayi berat lahir rendah yang lahir dengan kelainan kongenital yaitu sebesar 6,3\%.10 Penelitian Mahayana (2012) menunjukkan hasil yang relevan, bayi berat lahir rendah yang lahir dengan kelainan kongenital hanya 2,9\%.11 Terdapat faktor lain yang dapat mempengaruhi kejadian kelainan kongenital pada bayi baru lahir, seperti kelainan genetik, ibu yang mengkonsumsi rokok, alkohol dan obat-obatan yang dapat menginduksi terjadinya kelainan kongenital. ${ }^{30}$

Sebagian besar BBLR lahir dari kehamilan tunggal. Hanya sebagian kecil bayi yang lahir dari kehamilan ganda. Penelitian yang dilakukan oleh Mahayana (2015) sebagian besar bayi berat lahir rendah lahir dari gestasi tunggal $(76,4 \%)$ dan hanya $23,6 \%$ bayi berat lahir rendah yang lahir dari gestasi multipel. ${ }^{11}$

\section{Simpulan}

Sampel bayi pada penelitian ini paling banyak berada pada kategori BBLR, lahir dengan kondisi preterm dan berada pada klasifikasi SMK. Berdasarkan faktor risiko, bayi pada penelitian ini sebagian besar lahir dari usia ibu tidak berisiko, paritas multipara dan nullipara, jarak kehamilan tidak berisiko, riwayat kunjungan ANC tidak 
berisiko, dan ibu tidak anemia, pendidikan ibu yang rendah, sosial ekonomi rendah dan penyakit penyerta selama hamil. Pada penelitian ini hanya sebagian kecil bayi yang lahir dari ibu dengan kelainan plasenta, lahir dengan kelainan kongenital dan lahir dari kehamilan ganda.

\section{Ucapan Terima Kasih}

Terima kasih kepada para Staff Rekam Medis RSUP Dr. M. Djamil Padang yang telah membantu pengumpulan dan penyediaan data penelitian.

\section{Daftar Pustaka}

1. Kementerian Kesehatan RI. Profil kesehatan Republik Indonesia 2012. Jakarta: Kemenkes RI; 2013

2. Susanty SD, Agus S. Kajian faktor penyebab kematian bayi di Kota Padang. Human Care Jurnal. 2018;3(2):105-18.

3. World Health Organization. Low birth weight policy brief. Geneva: WHO; 2014.

4. World Health Organization. Care of the preterm and low birth weight newborn: World Prematurity Day. Geneva: WHO 2018.

5. Kementerian Kesehatan RI. Potret sehat indonesia dari Riskesdas 2018. Jakarta : Kemenkes RI; 2018. https://www.kemkes.go.id/article/view/181102000 03/potret-sehat-indonesia-dari-riskesdas-2018.html.

6. Dinas Kesehatan Provinsi Sumatra Barat. Profil Dinas Kesehatan Sumatera Barat Tahun 2017. Padang : Dinkes Sumbar; 2017.

7. Dinas Kesehatan Kota Padang. Profil kesehatan kota Padang tahun 2018. Padang: Dinkes Kota Padang; 2019.

8. Gomella TL, Cunningham MD, Eyal FG. Neonatology. 7th ed. New York: McGraw-Hill Education; 2013.

9. Suryati. Faktor-faktor yang memengaruhi kejadian BBLR di wilayah kerja Puskesmas Air Dingin. Jurnal Kesehatan Masyarakat Andalas. 2013;8(2):72-8

10. Indrasari N. Faktor resiko pada kejadian berat badan lahir rendah (Bblr). Jurnal Keperawatan. 2012; 8(2):114-123.

11. Mahayana SAS, Chundrayetti E, Yulistini. Faktor risiko yang berpengaruh terhadap kejadian berat Lahir Rendah di RSUP Dr. M. Djamil Padang. Jurnal Kesehatan Andalas. 2015;4(3):664-73.

12. Fatimah N, Utama BI, Sastri S. Hubungan antenatal care dengan kejadian bayi berat lahir rendah pada ibu aterm di RSUP Dr. M . Djamil Padang. Jurnal Kesehatan Andalas 2015;6(3):615-20.

13. Demelash H, Motbainor A, Nigatu D, Gashaw K, Melese A. Risk factors for low birth weight in Bale zone hospitals, South-East Ethiopia: A case-control study. BMC Pregnancy Childbirth. 2015;15(264) : 110.

14. Hapsari AL. Gambaran faktor risiko dan lama rawat bayi berat lahir rendah di RSU Kota Tangerang Selatan(skripsi). Jakarta : Universitas Islam Negeri Syarif Hidayatullah; 2017.

15. Septa W, Darmawan M. Faktor risiko bayi berat badan lahir rendah di RS PKU Muhammadiyah Yogyakarta tahun 2010. Jurnal Kedoteran kesehatan Indonesia. 2011;3(8):45-51.
16. Putri AW, Pratitis A, Luthfiya L, Wahyuni S, Tarmali A. Faktor Ibu terhadap kejadian bayi berat lahir rendah. HIGEIA Jurnal of PUBLIC Health research and development. 2017;3(1)14-24.

17. Purba SJA, Wilar R, Gunawan S. Status antropometri pada bayi yang dirawat di neonatal intensive care unit rsup prof. dr. r. d. kandou manado. Jurnal Medik dan Rehabilitasi. 2019; 1(3): 1-4.

18. Ifalahma D, Wulandari FI. Hubungan penambahan berat badan ibu selama hamil dengan berat badan bayi baru lahir di $\mathrm{Rb}$ An-Nuur Karanganyar. Infokes.2015; 5(2): 23-33.

19. Saifuddin A. Buku acuan national pelayanan kesehatan anak maternal dan neonatal. Yayasan Bina Sarwono Prawirohardjo: Jakarta; 2010

20. Kristiana, Noni, Elvi J. Umur, pendidikan, pekerjaan dan pengetahuan dengan kejadian berat badan lahir rendah (BBLR). Wawasan Kesehatan. 2017;4(1).

21. Kementerian Kesehatan RI. Pedoman pelayanan antenatal terpadu. Jakarta: Kemenkes RI; 2010

22. Ginandjar P, Saraswati LD. Gambaran faktor ibu terkait deteksi dini kehamilan berisiko di Kabupaten Brebes. J Kesmasindo. 2013;5(1):44-51.

23. Hussain S, Ahmed S, Tarar SH, Tasleem G. low birth weight: frequency, demographic profile, and association with maternal risk factor at a Tertiary Care Teaching Hospital. Pak Armed Forces Med J. 2018; 68(4): 850-55

24. Prawirohardjo S. Ilmu kebidanan. Jakarta: PT Bina Pustaka Sarwono Prawirohardjo; 2008.

25. Borah M, Agarwalla R. Maternal and sociodemosgraphic determinants of low birth weight (LBW): A community-based study in a rural block of Assam. J Postgr Med. 2016;62(3):178-181.

26. Begum P, Hassan Mk, Akter T, Arifin M. Risk factors of low birth weight baby. Faridpur Med Coll J 2017; 12(1): 40-46.

27. Deshpande Jayant D, Phalke DB, Bangal VB, Peeyuusha BS. Maternal risk factors for low birth weight neonates: A hospital based case-control study in rural area of Western Maharashtra, India. Natl J Community Med. 2011; 2(3):394-398.

28. Contrada RJ, Baum A. The handbook of stress science: biology, psychology, and health. New York : Springer Publishing Company; 2011

29. Altuncu E, Kanvuncuo S, Gokmirza PO, Albayrak Z, Arduc A. The incidence of low birth weight in 5000 liveborn infants and the etiology of fetal risk factors. Marmara Medical Journal. 2006;19(12):46-51.

30. Polii EG, Wilar R, Umboh A. Faktor risiko yang berhubungan dengan kejadian kelainan bawaan pada neonatus di RSUP Prof Dr. R. D. Kandou Manado. Jurnal e-Clinic. 2016; 4(2). 